\title{
Repente da Resistência
}

Maria Tereza Queiroz Carvalho²

Não tem posse

Nem sobre o próprio corpo.

Este, que mais parece um estorvo.

E toda essa gente,

Quase que nada mais sente.

Tanta gente sem terra,

Tanta terra sem gente.

\author{
A semente na mente \\ Peleja para germinar. \\ Levanta povo! \\ Esse estar demente \\ Precisa se libertar.
}

2 Advogada (OAB/MG -164.400), Bacharel em Direito pela Universidade Estadual de Montes Claros (UNIMONTES). Tem experiência profissional como técnico-administrativa, bem como no Direito, a partir dos estágios em Escritório de Advocacia, na $5^{\mathrm{a}}$ Vara Cível de Montes Claros e no Serviço de Assistência Jurídica da Unimontes (SAJ). Dedicou sua graduação também à pesquisa de temas relacionados à Crítica Jurídica, Direito de Povos e Comunidades Tradicionais e Participação Popular no âmbito jurídico, sendo que seu Trabalho de Conclusão de Curso (TCC) foi uma das resultantes desses anos de estudo. E-mail: tera.unimoc@yahoo.com.br 
Tanta gente sem casa,

Tanta casa sem gente.

No repique e no repente

Ganho asas de beija-flor.

Olhar de amor.

Pele diamante negro.

Para você eu escrevo

Batucar no tambor.

Se o amor for labuta

Daqui não saio.

Morro na luta. 